\title{
Biotechnological Potential of Alternative Carbon Sources for Production of Pectinases by Rhizopus microsporus var. rhizopodiformis
}

\author{
André Ricardo de Lima Damásio ${ }^{1}$, Alexandre Maller ${ }^{1}$, Tony Márcio da Silva ${ }^{2}$, João Atílio \\ Jorge $^{2}$, Hector Francisco Terenzi ${ }^{2}$ and Maria de Lourdes Teixeira de Moraes Polizeli ${ }^{2 *}$ \\ ${ }^{1}$ Departamento de Bioquímica e Imunologia; Faculdade de Medicina de Ribeirão Preto; Universidade de São \\ Paulo; Av. Bandeirantes, 3900; 14040-901; Ribeirão Preto - SP - Brasil. ${ }^{2}$ Departamento de Biologia; Universidade \\ de São Paulo; Av. Bandeirantes, 3900; 14040-901; Ribeirão Preto - SP - Brasil
}

\begin{abstract}
Fungi collected from Brazilian soil and decomposing plants were screened for pectinase production. R. microsporus var. rhizopodiformis was the best producer and was selected to evaluate the pectic enzyme production under several nutritional and environmental conditions. The pectinase production was studied at $40^{\circ} \mathrm{C}$, under 28 carbon sourcessupplemented medium. The inducer effect of several agro-industrial residues such as sugar cane bagasse, wheat flour and corncob on polygalacturonase (PG) activity was 4-, 3-and 2-fold higher than the control (pectin). In glucose-medium, a constitutive pectin lyase (PL) activity was detected. The results demonstrated that $\mathrm{R}$. microsporus produced high levels of $P G(57.7 \mathrm{U} / \mathrm{mg})$ and $P L(88.6 \mathrm{U} / \mathrm{mg})$ in lemon peel-medium. PG had optimum temperature at $65{ }^{\circ} \mathrm{C}$ and was totally stable at $55^{\circ} \mathrm{C}$ for $90 \mathrm{~min}$. Half-life at $70^{\circ} \mathrm{C}$ was 68 min. These results suggested that the versatility of waste carbon sources utilization by R. microsporus, produce pectic enzymes, which could be useful to reduce production costs and environmental impacts related to the waste disposal.
\end{abstract}

Key words: agro industrial residues, lemon peel, pectin lyase, polygalacturonase, $R$. microsporus var. rhizopodiformis

\section{INTRODUCTION}

Celluloses, hemicelluloses and pectic substances are the most abundant carbohydrates present in the plant cell walls. Pectic substances such as pectin, protopectin and pectic acids are present in the middle lamella and contribute to firmness and structure to the plant tissues. In the pectic substances, D-galacturonic acid units are linked by $\alpha-1,4-$ glycosidic linkages and the carbonyl side groups are $60-90 \%$ esterified with methanol (Gummadi and Panda, 2003).

Pectins are naturally degraded by the pectinolytic enzymes, which have been classified on the basis of their mechanism of attack on the galacturonan backbone. Pectin degrading enzymes can be divided into esterases and depolymerases (RexováBenková and Markovic, 1976). The first group is represented by pectin esterase (PE) and the second by polygalacturonase (PG) and pectin lyase (PL).

*Author for correspondence: polizeli@ ffclrp.usp.br 
PG (EC 3.2.1.15) is a depolymerizing pectinase that catalyzes the hydrolysis of $\alpha-(1,4)$ glycosidic bounds between the non-esterified galacturonic acid units (Mohamed et al., 2006). Pectate lyase (EC 4.2.2.2) and PL (EC 4.2.10.10) cleave $\alpha-1,4-$ glycosidic linkages by trans-elimination, which results in galacturonide with an unsaturated bond between $\mathrm{C} 4$ and $\mathrm{C} 5$ at the non-reducing end of the galacturonic acid formed.

Pectinases can be used in several industrial processes as fruit juices and wine production, tea and coffee fermentation or olive oil recovery, vegetable oil extraction, functional foods, improvement of cassava starch extraction, textile industry, paper and cellulose industry and animal feeds (Gummadi and Panda, 2003). Pectinases have also been used in the paper and pulp industry in addition to cellulases (Reid and Ricard, 2000), due to its presence in the plant host microorganisms (Hershonhorn et al., 1990; Lang and and Dornenburg, 2000).

Brazil has a prominent role in the production and exportation of coffee, sugar cane, soybean, fruit and other products. However, industrial processing of these items results in the generation of huge amount of other materials. Some applications suggested for these residues are their utilization as substrates for microbial fermentation bioprocesses, to obtain valuable products, such as enzymes, alcohol, proteins, organic acids, amino acids, bioactive and flavour compounds (Medeiros et al., 2000).

The Tahiti lemon is a fruit of tropical origin, with recent economic exploration. In the world context, the main producers are Mexico, USA, Egypt, India, Turkey and Brazil. The "albedo", which corresponds the spongy portion, white and adherent to the peel, is rich in hemicellulose, cellulose, pectic substances, soluble carbohydrate, lignin and phenolic compounds (Ros et al., 1996). The aim of this work was to select the fungi from the soil or decomposing plants, with the components for good production of pectinases and to evaluate the effects of several carbon sources and environmental conditions on fungal pectinase production by the selected strains.

\section{MATERIALS AND METHODS}

\section{Organisms and maintenance}

Ten fungi were isolated from the soil and plants waste from different areas of São Paulo and
Paraná states, Brazil, as previously cited by Guimarães et al. (2006) and these were cultivated on PDA medium at $40^{\circ} \mathrm{C}$. The investigated areas were located at $S 21^{\circ} 09.190^{\prime}-45^{\circ} 52.150^{\prime} \mathrm{W}$, in the municipality of Ribeirão Preto, SP (Aspergillus phoenicis, A. ochraceus, Mucor rouxii, Humicola grisea var. thermoidea and Scytalidium

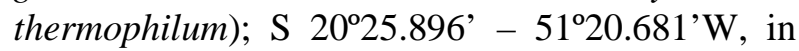
the municipality of Ilha Solteira, SP (A. caespitosus and $P$. variotii); S 21 $1^{\circ} 55.626^{\prime}-$ $47^{\circ} 28.109^{\prime} \mathrm{W}$, in the municipality of Pirassununga, SP (Rhizopus microsporus var. rhizopodiformis); S 245' $21^{\prime}$ ' $-53^{\circ} 27^{\prime} 19^{\prime}$ ' $\mathrm{W}$ in the municipality of Cascavel, PR (Penicillium herquei). The fungi were inoculated in Czapeck medium at $40^{\circ} \mathrm{C}$ with agitation (100 rpm) for three days to screen pectinases production. Rhizopus microsporus var. rhizopodiformis was selected as the best pectinase producer among the isolated fungi. The fungus was identified by André Tosello Foundation, Campinas, SP, (OS 990300) according to Schipper and Stalpers (1984).

\section{Growth conditions}

For the production of $\mathrm{PG}$ the submerged fermentation $(\mathrm{SmF})$ of approximately $3 \times 10^{5}$ spores $/ \mathrm{ml}$ from 15-day-old cultures were inoculated into $125 \mathrm{ml}$ Erlenmeyer flasks containing $25 \mathrm{ml}$ of Adams medium (Adams, 1990) with $1.0 \%$ citric pectin (w/v) or other carbon sources, (monogalacturonic acid, polygalacturonic acid, corncob, orange peel, lemon peel, oatmeal, apple peel, sugar cane bagasse, passion fruit peel, gum guar, sucrose, cassava flour, penetrose, raffinose, wheat bran, galactose, rice straw, trehalose, arabinose, glucose and milled corn). The cultures were incubated at $40^{\circ} \mathrm{C}$ with agitation (100 rpm) for five days. Other liquid media compositions were also tested which included Khanna (Khanna et al., 1995), SR (Rizzatti et al., 2001), Czapeck (Wiseman, 1975) and Vogel (Vogel, 1964).

\section{Preparation of crude enzyme}

The culture filtrates were obtained by filtration through Whatman No. 1 paper in a Buchner funnel. The filtrate was saved as a source of crude extracellular PG. The mycelial mass was ground with glass beads at $4^{\circ} \mathrm{C}$.

\section{Enzymatic assays and protein determination}

PG activity assay was carried out according to Miller (Miller, 1959). This enzyme was assayed at 
$65^{\circ} \mathrm{C}$ (temperature optimum - see results), in a reaction mixture containing $0.25 \mathrm{ml}$ of enzyme and $0.25 \mathrm{ml}$ of $1.0 \%$ sodium polypectate in $100 \mathrm{mM}$ sodium acetate buffer, $\mathrm{pH} 3.5(\mathrm{pH}$ optimum - see results). One unit was defined as the amount of enzyme that released one $\mu \mathrm{mol}$ of reducing sugar per minute under the assay conditions. PL activity was assayed according to Pitt (1988). One unit was defined as the amount of enzyme that changed the absorbance of 0.01 at 550 $\mathrm{nm}$ under the assay conditions. Pectate lyase activity was assayed according to Collmer and Ried, (1988). One unit was defined as the amount of enzyme that released one $\mu \mathrm{mol}$ of unsaturated digalacturonate per minute under the assay conditions. The growth was estimated as protein of the mycelial extract (total $\mathrm{mg}$ ), according to Lowry et al. (1951) using bovine serum albumin as standard.

\section{Effects of temperature and $\mathrm{pH}$}

The crude extract obtained from the lemon peel as carbon source was used to evaluate the PG activity as a function of $\mathrm{pH}$ in Mcllvaine buffer $(\mathrm{pH} 3.0-$ $8.0)$ at $65^{\circ} \mathrm{C}$ with $1 \%$ sodium polypectate (NaPP) as substrate. The effect of temperature on $\mathrm{PG}$ activity was analysed in McIlvaine buffer incubated between 30 and $80^{\circ} \mathrm{C}$ at the optimum
$\mathrm{pH}$. The thermal stability was investigated by measuring the residual activity of the enzyme after 90 min of incubation at $30-80^{\circ} \mathrm{C}$.

\section{Reproducibility of the results}

All data are the mean of at least three independent experiments showing consistent results.

\section{RESULTS}

Fungi are interesting enzyme sources for biotechnological application. Among the various filamentous fungi collected (maintained at $40^{\circ} \mathrm{C}$ in the plates with $4 \%$ solid oatmeal medium) (Fig. 1), Rhizopus microsporus var. rhizopodiformis produced the highest PG levels. There was no report in the literature about this thermotolerant strain as a PG producer. This fungus is a thermotolerant fungus, identified and deposited in the André Tosello Foundation (Brazil). The fungus was cultivated in five different media for pectinase production under agitation (100 rpm) for five days at $40^{\circ} \mathrm{C}$. The enzymes were assayed in the culture filtrate. The best enzymatic yields were obtained in Adams medium (Fig. 2).

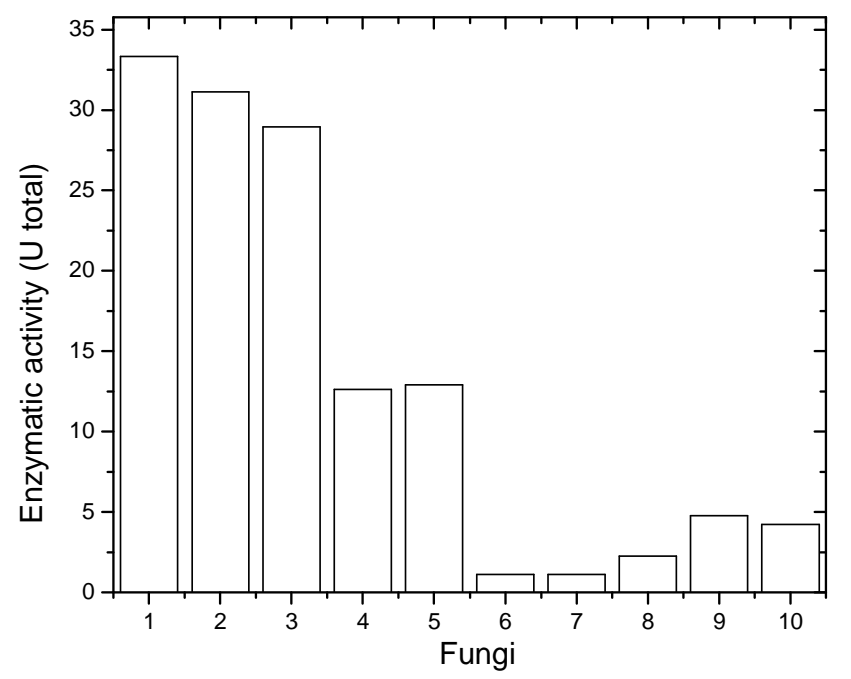

Figure 1 - Pectinases screening. 1) Rhizopus microsporus var. rhizopodiformis; 2) Penicillium herquei; 3) Aspergillus caespitosus; 4) Aspergillus phoenicis; 5) Aspergillus ochraceus; 6) Paecilomyces variotii; 7) Humicola insolens; 8) Humicola grisea var. thermoidea; 9) Mucor rouxii; 10) Scytalidium thermophilum. The fungi were inoculated in Czapeck medium, at $40^{\circ} \mathrm{C}$, with agitation (100 rpm) for 3 days. 


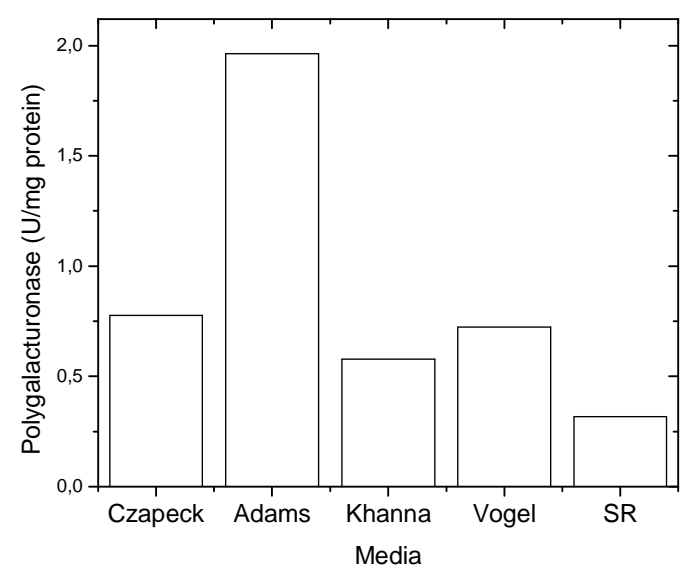

Figure 2 - Production polygalacturonase by $R$. microsporus var. rhizopodiformis in different culture media.

\section{Time-course of pectinases production}

The fungus was inoculated in Adams medium supplemented with $1 \%(\mathrm{w} / \mathrm{v})$ Sigma ${ }^{\circledR}$ citric pectin as carbon source. The maximun PG production was after $72 \mathrm{~h}$ (Fig. 3A), (also the highest amount of micelial mass) (Fig. 3B). A decrease in enzymatic synthesis occurred after $72 \mathrm{~h}$, probably due to the inhibition of the enzyme by the endproducts. The highest PL production was detected after $48 \mathrm{~h}$ of culture. Pectate lyase levels were only detected after $120 \mathrm{~h}$.

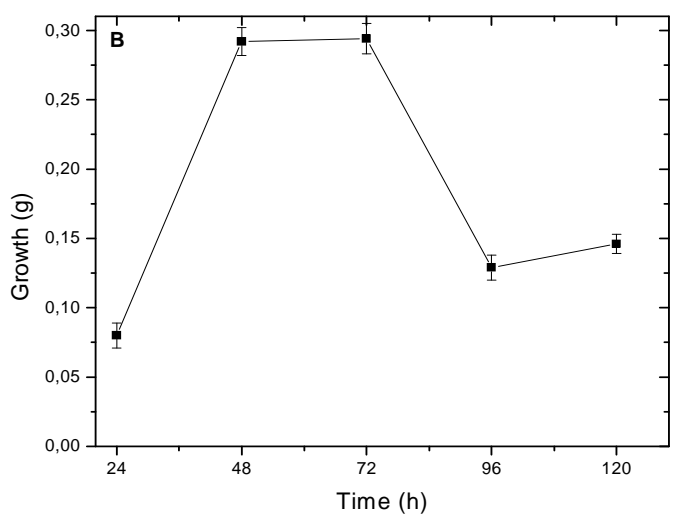

Figure 3 - Time course of pectinases production (A) and growth of the microorganism (B) in cultures under agitation (100 rpm).

\section{Effect of carbon sources on pectinases production \\ Polygalacturonase}

Table 1 shows the influence of carbon sources on the $R$. microsporus var. rhizopodiformis PG production, cultivated for $72 \mathrm{~h}$ at $40^{\circ} \mathrm{C}$ under agitation $(100 \mathrm{rpm})$ in Adams medium. The most effective inducer carbon source was lemon peel, increasing up to 5-fold the PG production compared with $1 \%$ Sigma $^{\circledR}$ pectin (control). Under glucose addition, some constitutive PG synthesis was detected, with low activity levels, close to those observed in the absence of additional carbon sources. For the pectins with different methylation degrees, PG production was higher than the control and the extent of enzyme production decreased with an increase in the degree of esterification.

\section{Pectin lyase}

Several carbon sources were tested for PL induction (Table 1). The highest activity was 
found for polygalacturonic acid and lemon peelsupplemented cultures. In the presence of glucose, a constitutive PL activity was observed. In the absence of a carbon source no enzymatic activity was detected.

Effect of temperature and $\mathrm{pH}$ on polygalacturonase activity

The optimum temperature and $\mathrm{pH}$ for PG activity were $65^{\circ} \mathrm{C}$ and 3.5 , respectively (Figs. $4 \mathrm{~A}$ and $\mathrm{C}$ ). The thermostability assay (Fig. 4B) was carried out with the extract incubated at 55, 60, 65 and $70^{\circ} \mathrm{C}$, for $90 \mathrm{~min}$ under the absence of the substrate and after that the enzymatic assays were carried out. The enzymatic activity decreased about 28 and $39 \%$ at 60 and $65^{\circ} \mathrm{C}$, respectively. At $70^{\circ} \mathrm{C}$ it was possible to calculate the $t_{50}(68 \mathrm{~min}$.), which showed a reduction of $50 \%$ in the PG activity.

Table 1 - Effect of different carbon sources on the production of polygalacturonase and pectin lyase by $R$. microsporus var. rhizopodiformis.

\begin{tabular}{|c|c|c|}
\hline Carbon sources (1\%) & Polygalacturonase (U/mg) & Pectin Lyase (U/mg) \\
\hline None & 0.001 & 0.001 \\
\hline Lemon peel & 57.7 & 88.57 \\
\hline Monogalacturonic acid & 40.9 & 32.89 \\
\hline Polygalacturonic acid & 37.0 & 100.9 \\
\hline Pectin citrus (GM 9\%) & 30.3 & 50.75 \\
\hline Pectin citrus (GM 30\%) & 23.3 & 43.30 \\
\hline Pectin citrus (GM 70\%) & 19.1 & 79.90 \\
\hline Corncob & 18.5 & 18.13 \\
\hline Pectin (Sigma) & 11.2 & 60.32 \\
\hline Orange peel & 12.5 & 0.001 \\
\hline Oatmeal & 9.54 & 11.46 \\
\hline Apple peel & 8.04 & 0,001 \\
\hline Sugar cane bagasse & 6.95 & 35.08 \\
\hline Passion fruit peel & 4.85 & 0.001 \\
\hline Gum guar & 4.45 & 0.001 \\
\hline Sucrose & 3.93 & 0.001 \\
\hline Cassava flour & 3.27 & 24.62 \\
\hline Penetrose & 3.18 & 47.89 \\
\hline Raffinose & 3.17 & 0,001 \\
\hline Wheat bran & 2.71 & 12.18 \\
\hline Galactose & 2.50 & 0.001 \\
\hline Rice straw & 2.44 & 26.01 \\
\hline Trehalose & 2.34 & 34.06 \\
\hline Arabinose & 2.31 & 35.76 \\
\hline Glucose & 1.78 & 62.72 \\
\hline Milled corn & 1.75 & 13.11 \\
\hline
\end{tabular}

${ }^{a}$ None: Adams medium without sugar or agro industrial residues addition..

\section{DISCUSSION}

This study evaluated the environmental and nutritional influence on pectinase production by $R$. microsporus var. rhizopodiformis, cultivated in submerged culture. Adams medium showed the best composition for the fungus growth and enzyme production. Other media also supported significant enzymatic yield. For example, potatodextrose liquid medium plus $0.1 \%$ citric pectin for
Trichoderma harzianum (Mohamed et al., 2006), or Kebede medium for Kluyveromyces wickerhamii (Moyo et al., 2003).

Pectinolytic enzyme production has been reported as carbon source dependents (Gummadi and Panda, 2003; Blandino et al., 2001), as well as pH (Malvessi and Silveira, 2004), and temperature, culture time, aeration, and other parameters (Souza et al., 2003). For the growth time-course and pectinolytic enzyme production, $R$. microsporus 
var. rhizopodiformis showed a good adaptation in Adams medium. The logarithmic phase was welldefined; it started around $24 \mathrm{~h}$ and finished at around $48 \mathrm{~h}$. Talaromyces flavus pectic enzyme

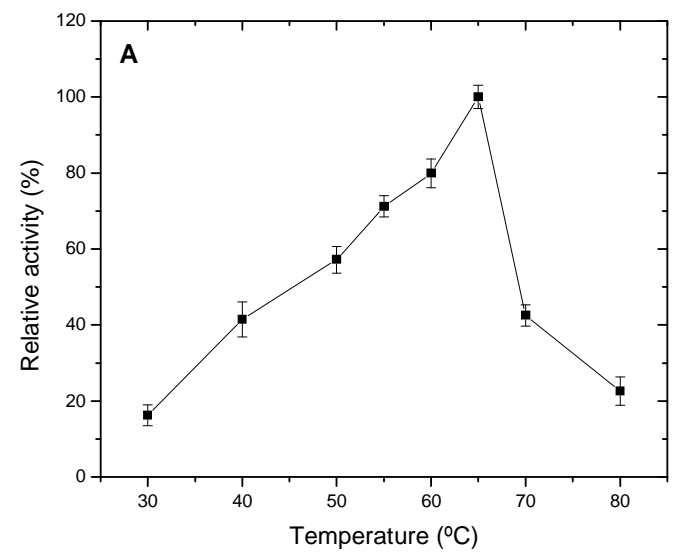

production was also maximum in $48 \mathrm{~h}$ (Crotti et al., 1999) in Manachini medium (Manachini et al., 1988) supplemented with $0.8 \%(\mathrm{w} / \mathrm{v})$ pectin at $30^{\circ} \mathrm{C}$ under constant agitation.
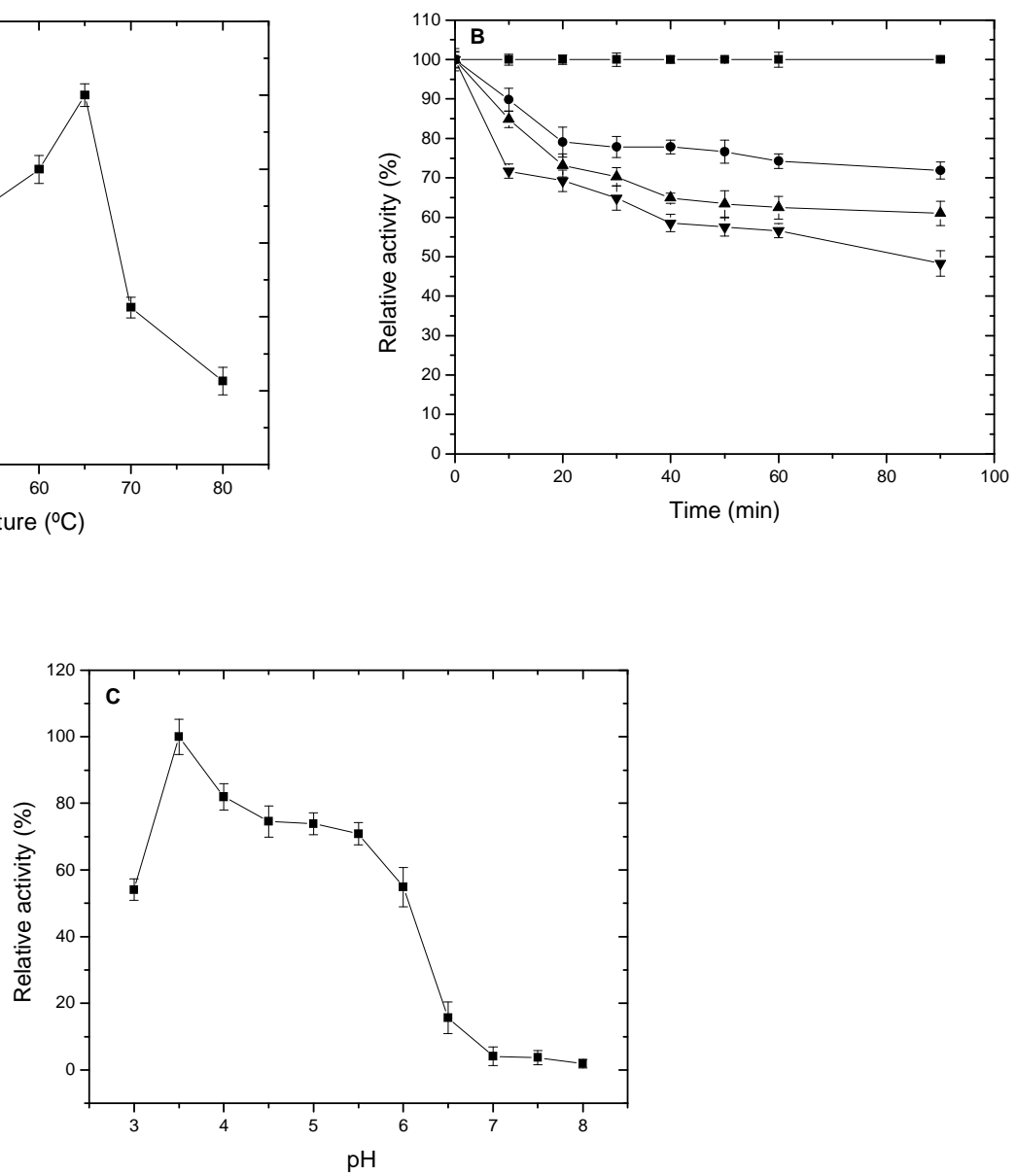

Figure 4 - Influence of temperature (A and $\mathrm{B}$ ) and $\mathrm{pH}(\mathrm{C})$ on polygalacturonase activity. Determination of optimum temperature (A) was carried out at $\mathrm{pH} 3.5$. Thermal inactivation (B) was carried out at $55^{\circ} \mathrm{C}(\boldsymbol{\square}), 60^{\circ} \mathrm{C}(\bullet), 65^{\circ} \mathrm{C}(\boldsymbol{\Delta})$ or at $70^{\circ} \mathrm{C}(\boldsymbol{\nabla})$. The assay of determination of optimum $\mathrm{pH}$ (C) was carried out at $65^{\circ} \mathrm{C}$.The polygalacturonase activity was estimated by the DNS method using sodium pectate as substrate.

The agro industrial residues used for the enzyme production represent an economic alternative for the carbon sources and also contribute to decrease the pollution concern about waste accumulation in the environment, therefore they have been frequently studied (Martin et al., 2004). Lemon peel was an interesting carbon source for PG production. Ros et al. (1996) worked with different variety of pectic substances from the lemon "albedo" cell walls, where alcohol insoluble solids were extracted to obtain a chelating agent soluble pectin fraction (ChSS), a diluted sodium hydroxide soluble pectin fraction (ASS) which was separated into a water soluble and water insoluble part (ASSws and ASSwi), and an insoluble residue (Residue). ChSS, ASSws, ASSwi and residue represented 64.3, 10.4, 0.4 and $8.1 \%$ of the galacturonic acid residues present in the lemon "albedo", respectively. 
A marked feature of the lemon "albedo" is the exceptionally high level of pectin throughout the cell walls from early on fruit development (Bain, 1958). They found that over $25 \%$ of the CWM (Cell Wall Material) of the immature lemon "albedo" consisted of galacturonic acid, the main constituent of pectin. Although the yield of CWM decreased during the maturation this level of galacturonic acid is maintained until the fruit is ripe. The non-cellulosic monosaccharide composition of cell wall material isolated from lemon "albedo" was 3.4 mol \% rhamnose, $1.1 \mathrm{~mol}$ $\%$ fucose, $29.2 \mathrm{~mol} \%$ arabinose, $5.2 \mathrm{~mol} \%$ xilose, $2.1 \mathrm{~mol} \%$ mannose, $16.5 \mathrm{~mol} \%$ galactose, 4.1 mol \% (glucose) and 38.5 mol \% galacturonic acid (Ros et al., 1988).

$R$. microsporus var. rhizopodiformis produced $\mathrm{PG}$, which exhibited an optimum temperature $\left(65^{\circ} \mathrm{C}\right)$ suitable for future biotechnological applications. Mohamed et al. (2006), reported a T. harzianum PG with optimum temperature at $40^{\circ} \mathrm{C}$, which retained $30 \%$ of its activity at $60^{\circ} \mathrm{C}$. The optimum temperature for PG from Bacillus sp. (Kobayashi et al., 2001) and T. reesei (Mohamed et al., 2003) were around 40 and $50^{\circ} \mathrm{C}$, respectively. Channe and Shewal (1995) studied a PG from Sclerotium rolfsii with optimum temperature at $55^{\circ} \mathrm{C}$. The enzymatic activity decreased 28,39 and $51 \%$ after incubation for $90 \mathrm{~min}$ at 60,65 and $70^{\circ} \mathrm{C}$, respectively. The thermal inactivation of the $T$. harzianum (Mohamed et al., 2006) PG was investigated by incubating the enzyme for 15,30 and $60 \mathrm{~min}$, at 10 to $100^{\circ} \mathrm{C}$ in the absence of substrate. The PG from T. reesei was stable at 40 and $50^{\circ} \mathrm{C}$ (Mohamed et al., 2003).

The present work showed that agro industrial wastes, especially, lemon peel, improved the PG and PL production by the thermotolerant fungus $R$. microsporus var. rhizopodiformis. The agro industrial residues used for the enzyme production represent alternative carbon sources, and also contribute to decrease the pollution concern about waste accumulation in the environment. These alternative carbon sources might reduce the enzyme production costs too.

\section{ACKNOWLEDGEMENTS}

This work was supported by the grants from Fundação de Amparo à Pesquisa do Estado de São Paulo (FAPESP) and Conselho de Desenvolvimento Científico e Tecnológico (CNPq). H. F. T.; J. A. J.; M. L. T. M. P. are Research Fellows of CNPq. A.R.L.D.; A.M; T.M.S. are recipient of the FAPESP Fellowship. We thank Ricardo Alarcon and Mauricio de Oliveira for technical assistance.

\section{REFERENCES}

Adams, P.R. (1990), Mycelial amylase activities of thermophilic species of Rhizomucor, Humicola and Papulaspora, Mycopathol., 12, 35-37.

Bain, J.M. (1958), Morphological, anatomical, and physiological changes in the developing fruit of the Valencia orange, Citrus sinensis (L.), Osbeck. Austr. J. Bot., 6, 1-24.

Blandino, A., Dravillas, K., Cantero, D., Pandiella, S. S., Webb, C. (2001), Utilisation of whole wheat flour for the production of extracellular pectinases by some fungal strains, Process Biochem., 37, 497-503.

Channe, P.S., Shewal, J.G. (1995), Pectinase production by Sclerotium rolfsii: Effect of culture conditions, Folia Microbiol., 40, 111-117.

Collmer, A., Ried, J.L., Mount, M.S. (1988), Assay methods for pectic enzymes, Meth. Enzymol., 161, 326-335.

Crotti, L.B., Jabor, V.A., Chellegatti, M.A., Fonseca, M.J., Said, S. (1999), Studies of pectic enzymes produced by Talaromyces flavus in submerged and solid substrate cultures, J. Basic Microbiol., 39, 227235.

Guimarães, L.H., Peixoto-Nogueira, S.C., Michelin, M., Rizzatti, A.C.S, Sandrim, V.C., Zanoelo, F.F., Aquino, A.C.M.M, Junior, A.B., Polizeli, M.L.T.M. (2006), Screening of filamentous fungi for production of enzymes of biotechnological interest, Braz. J. Microbiol., 37, 474-480.

Gummadi, S.N., Panda, T. (2003), Purification and biochemical properties of microbial pectinases - a review, Process Biochem., 38, 987-996.

Hershonhorn, J., Manulis, S., Barash, I. (1990), Polygalacturonase associated with infection of Valencia orange by Penicillium italicum, Phytopathol., 80, 1374-1376. 
Khanna, P., Sundari, S.S., Kumar, N.J. (1995), Production, isolation and partial purification of xylanase from Aspergillus sp, World J. Microbiol. Biotechnol., 11, 242-243.

Kobayashi, T., Higaki, N., Suzumatsu, A., Sawada, K., Hagihara, H., Kawai, S., Ito, S. (2001), Purification and properties of a high molecular-weight,alkaline exopolygalacturonase from strain of Bacillus, Enzyme Microb. Technol., 29, 70-75.

Lang, C., Dornenburg, H. (2000), Perspectives in the biological function and the technological application of polygalacturonases, Appl. Microbiol. Biotechnol., 53, 366-375.

Lowry, H., Rosebrough, N.J., Farr, A.L., Randal, R.J. (1951), Protein measurement with the Folin phenol regent, J. Biol. Chem., 193, 267-275.

Malvessi, E., Silveira, M. M. (2004), Influence of medium composition and $\mathrm{pH}$ on the production of polygalacturonase by Aspergillus oryzae, Braz. Arch. Biol. Technol., 47, 693-702.

Manachini, P.L., Parini, C., Fortina, M.G. (1988), Pectic enzymes from Aureobasidium pullulans L.V.10, Enzyme Microb. Technol., 10, 682-685.

Martin, N., Souza, S. R., Silva, R., Gomes, E. (2004), Pectinase production by fungal strains in solid-state fermentation using agro-industrial bioproduct, Braz. Arch. Biol. Technol., 47, 813-819.

Medeiros, A.B.P., Pandey, A., Freitas, R.J.S, Christen, P., Soccol, C.R. (2000), Optimization of the production of aroma compounds by Kluyveromyces marxianus in solid-state fermentation using factorial design and response surface methodology, Biochem. Eng. J., 6, 33-39.

Miller, G.L. (1959), Use of Dinitrosalicylic Acid reagent for determination of reducing sugar, Anal. Chem., 31, 426 - 429.

Mohamed, S.A., Christensen, T.M.I.E, Mikkelsen, J.D. (2003), New polygalacturonases from Trichoderma reesei: characterization and their specificities to partially methylated and acetylated pectins, Carbohydr. Res., 338, 515-524.

Mohamed, S.A., Farid, N.M., Hossiny, E.N., Bassuiny, R.I. (2006), Biochemical characterization of an extracellular polygalacturonase from Trichoderma harzianum, J. Biotechnol., 127, 54-64.
Moyo, S., Gashe, B.A., Collison, E.K., Mpuchane, S. (2003), Optimising growth conditions for the pectinolytic activity of Kluyveromyces wickerhamii by using response surface methodology, Int. J. Food Microbiol., 85, 87- 100.

Pitt, M. (1988), Pectin lyase from Phoma medicaginis var. pinodella, Methods Enzymol., 161, 350-354.

Reid, I., Ricard, M. (2000), Pectinase in papermaking solving retention problems in mechanical pulps bleached with hydrogen peroxide, Enzyme Microb. Technol., 26, 115-123.

Rexová-Benková, L., Markovic, O. (1976), Pectic enzymes: Advances in Carbohydrate Chemistry and Biochemistry, Academic Press, NewYork, USA, pp. 323-385.

Rizzatti, A.C.S., Jorge, J.A., Terenzi, H.F., Rechia, C.G.V., Polizeli, M.L.T.M. (2001), Purification and properties of a thermostable extracellular $\beta$-Dxylosidase produced by thermotolerant Aspergillus phoenicis, J. Ind. Microbiol. Biotechnol. 26, 156-160.

Ros, J.M., Schols, H., Voragen, A.G.J. (1988), Lemon albedo cell walls contain distinct populations of pectic hairy regions, Carbohydr. Polym., 37, 159166.

Ros, J.M., Schols, H.A., Voragen, A.G.J (1996), Extraction, characterisation, and enzymatic degradation of lemon peel pectins, Carbohydr. Res., 282, 271-284.

Schipper, M. A. A., Stalpers, J. A. (1984), A revision of the genus Rhizopus, Stud. Mycol., 25, 34.

Soccol, C.R., Vandenberghe, L.P.S. (2003), Overview of applied solid-state fermentation in Brazil, Biochem. Eng. J., 13, 205-218.

Souza, J. V. B., Silva, E. S., Maia, M. L. S., Teixeira, M. F. S. (2003), Screening of fungal strains for pectinolytic activity: endopolygalacturonase production by Paecilomyces clavisporus 2A.UMIDA.1, Process Biochem.,39, 455-458.

Vogel, H.F. (1964), Distribution of lysine pathways among fungi: evolutionary implications, Am. Nat., 98, 435-446.

Wiseman, A. (1975), Handbook of Enzyme Biotechnology, Ltd John Wiley and Sons, p. 148. 